\title{
Combined effect of external ammonia and molt stage on the blue shrimp Litopenaeus stylirostris physiological response
}

Chantal Mugnier* and Carole Justou

Laboratoire d'Aquaculture Calédonien, IFREMER, BP2059, 98846 Nouméa Cedex, New Caledonia

*: Corresponding author : cmugnier@ifremer.fr, Tel.: +687-28-51-71; fax: +687-28-78-57

\begin{abstract}
:
The effect of ambient ammonia and molt stage on the physiological response of the blue shrimp Litopenaeus stylirostris was studied. Shrimps were submitted to $54.6 \mathrm{mg} \mathrm{l}^{-1}$ ammonia-N (1.76 mg $\mathrm{I}^{-1}$ $\mathrm{NH}_{3}-\mathrm{N}$ ) for 24 hours. Only shrimps in stages $C, D_{0}, D_{1}$ and $D_{2}$ were used for the analysis. Haemolymph was assayed for osmoregulatory capacity (OC), magnesium ion (Mg ion), total proteins, oxyhaemocyanin, lactate and glucose. Molt stage had an effect on $\mathrm{OC}, \mathrm{Mg}$ ion and total proteins in control shrimps, and on OC, Mg ion and lactate in treated animals. Ammonia treatment decreased OC and lactate, and increase $\mathrm{Mg}$ ion concentration in haemolymph, for all molt stages. It decreased significantly total proteins and oxyhaemocyanin for stages $D_{1}$ and $D_{2}$, and increased glucose concentration for stages $C$ and $D_{0}$. There was a combined effect of treatment and molt stage only on total proteins concentration. The effects of an external factor (ammonia), an internal one (molt stage) and the combination of both, and the usefulness of using physiological parameters measured in this study as tools to detect stress, are discussed.
\end{abstract}




\section{Introduction}

Farming of the blue shrimp Litopenaeus stylirostris in earthen ponds in New Caledonia is a developing industry. However, it is facing episodes of mortality due to a member of the Vibrionaceae $\underline{V}$. penaeicida (Costa et al., 1998), which can also be found in the haemolymph of apparently healthy shrimp (C. Goarant, pers. com.). Variations in environmental factors seem to have an impact on the mortalities observed (Mermoud et al., 1998). Environmental factors may induce a stress response in shrimps and, as a consequence, a decrease in immune defence and an increased susceptibility to pathogens (Le Moullac and Haffner, 2000; Horowitz and Horowitz, 2001). Ammonia-N concentration in ponds is one of the main environmental factors that can induce a stress in shrimp. In intensive culture system, accumulation of ammonia-N, which is the principal end-product of nitrogenous compounds, has a deleterious effect on fish and crustaceans (Colt and Armstrong, 1981). In water the equilibrium between unionised ammonia $\left(\mathrm{NH}_{3}\right)$ and ammonium ion $\left(\mathrm{NH}_{4}^{+}\right)$is $\mathrm{pH}-$, temperature- and salinity- dependent. Of the ammonia species, $\mathrm{NH}_{3}$ is the most toxic to aquatic life. The effects of ammonia-N on shrimp or other decapods physiological response are relatively well documented (Wajsbrot et al., 1990; Young-Lai et al., 1991; Chen and Cheng, 1993a; Schmitt and Uglow, 1997; Racotta and Hernandez-Herrera, 2000; Harris and al., 2001).

Despite moult cycle has an effect on numerous physiological functions in Crustacea, molt stage of the animal except intermolt has received little attention. However, it has been shown that shrimps at pre- and postmolt stages are more sensitive to stress than intermolt animals (Wajsbrot et al., 1990). Premolt animals are also less resistant 
to experimental infection with pathogenic bacteria than intermolt animals (Le Moullac et al., 1997; Cheng et al., 2003).

The aim of the present work was to study the physiological response of sub-adult $\underline{L}$. $\underline{\text { stylirostris }}$ to an environmental stress in relation with molt stage. So far this species has received little attention compared to $\underline{\text { Penaeus vannamei }}$ and $\underline{P \text {. monodon, }}$ which are the main cultivated species in the world. However, $\underline{\text { L. stylirostris }}$ is cultivated in America and the shrimp aquaculture in New Caledonia is devoted to this species. The aim of this work was also to test physiological indicators that can be assayed from a haemolymph sample in order to monitor and analyse shrimp response under environmental variations. Thus physiological responses in terms of osmotic regulation, and metabolic responses, to a sub-lethal level of ammonia-N corresponding to $2 \mathrm{mg} \mathrm{l}^{-1} \mathrm{NH}_{3}-\mathrm{N}$ were studied. Some physiological parameters that can be involved in stress response or be affected by stress were selected for this study. Variation of osmoregulatory capacity (OC), which is the difference in osmotic concentration between haemolymph and surrounding water, was studied as a nonspecific indicator commonly used for detecting physiological stresses, including in $\underline{\mathrm{L}}$. stylirostris (Lignot et al., 2000). Other selected parameters measurable in haemolymph are: total proteins, oxyhaemocyanin, magnesium $(\mathrm{Mg})$ ion, glucose and lactate. Total proteins can serve as a significant source of metabolic energy for crustaceans (Claybrook 1983). It was shown that protein concentration decreases under ammonia stress (Chen et al., 1993, Chen and Cheng 1993a). Oxyhaemocyanin is the main protein in the haemolymph and is implied in several functions like oxygen transport, enzymatic activities, osmoregulation or buffering (Paul and Pirow, 1997/98). The Mg ion plays an important role as a co-factor in enzyme systems and as a modulator of the hemocyanin of crustacean arthropods (Morrit and Spicer, 
1993), and variations of its concentration in shrimp haemolymph have been observed under different stress conditions (Boglio, 1995). Variations of blood glucose levels have been observed under several different environmental and physiological conditions (Hagerman et al., 1990; Hall and Van Ham, 1998). Lastly, lactate formation could be expected if a higher energy production is induced by environmental or physiological changes and anaerobic metabolism occures.

\section{Material and methods}

\subsection{Experimental animals}

The experiment took place in the Caledonian Aquaculture Laboratory of IFREMER in New Caledonia, on sub-adults (average weight $21.4 \pm 2.0 \mathrm{~g}$ ) of $\underline{\mathrm{L} \text {. stylirostris }}$ reared in an earthen growout pond. The shrimps were transported to five 2001 indoor tanks (20 shrimps per tank) with static aerated sea water at $25^{\circ} \mathrm{C}$ and a salinity of 32\%. They were acclimated for 2 days before the experiment started (Soyez, 1997) and were fed commercial pellets. They were not fed $12 \mathrm{~h}$ before and during the experiment. Faeces were removed during partial water exchange the days preceding the experiment.

\subsection{Moult stage determination}

Six moult stages were defined according to the retraction of the epithelium within setae of the antennal scale (Drach, 1939; Chan et al., 1988). Shrimps were classified as $\mathrm{A}$ and $\mathrm{B}$ for respectively the early and late post molt stages, $\mathrm{C}$ for intermolt and $D_{0}, D_{1}, D_{2}$ for premolt stages. $D_{2}$ was the late premolt stage prior to ecdysis, when 
epidermis is at maximal retraction and it is possible to distinguish the developing seta.

\subsection{Experimental procedure}

Shrimps were exposed for $24 \mathrm{~h}$ to a sub-lethal concentration of $2 \mathrm{mg} \mathrm{l}^{-1} \mathrm{NH}_{3}-\mathrm{N}$. Ammonia test solutions were prepared by dissolving the required amount of ammonium chloride in seawater. The amount of ammonium chloride to be added to obtain a $\mathrm{NH}_{3}-\mathrm{N}$ concentration of $2 \mathrm{mg} \mathrm{l}^{-1}$ was calculated according to the equation of Bower and Bidwell (1978) based on a salinity, $\mathrm{pH}$ and temperature of respectively $32 \%$, 7.81 and $25^{\circ} \mathrm{C}$. These parameters were measured again at the end of the experiment. Three tanks out of 5 received ammonium chloride.

After $24 \mathrm{~h}$ exposure to ammonia, haemolymph samples were collected via the ventral sinus using disposable syringes and needles and were immediately distributed as follows: A 10- $\mu 1$ subsample of haemolymph was used for measurement of osmotic pressure with a vapour pressure Wescor osmometer. A $60-\mu 1$ subsample was diluted in $1140 \mu \mathrm{l}$ of distilled water and oxyhaemocyanin absorbance was measured at 335 $\mathrm{nm}$ (characteristic of oxyhaemocyanin) using a Spectronic Genesys ${ }^{\mathrm{TM}} 5$ spectrophotometer within a maximum of $50 \mathrm{~min}$ after sampling. The oxyhaemocyanin concentration was calculated using an extinction coefficient $\left(E_{1 \mathrm{~cm}}^{\mathrm{mM}}\right)$ of 17.26 (Chen and Cheng, 1993b). A 135- $\mu$ l subsample of haemolymph was mixed with $15 \mu \mathrm{l}$ of $10 \%$ sodium citrate and centrifuged $5 \mathrm{~min}$ at $800 \mathrm{~g}, 5^{\circ} \mathrm{C}$. The supernatant (plasma) was stored at $-80^{\circ} \mathrm{C}$ for further biochemical analysis.

\subsection{Plasma constituent analysis}


A $50-\mu 1$ subsample of plasma was mixed with $100 \mu 1$ ice-cold $6 \% \mathrm{v} / \mathrm{v}$ perchloric acid and centrifuged for $15 \mathrm{~min}$ at $13000 \mathrm{~g}$ for deproteinisation. The supernatant was neutralized with $14 \mu \mathrm{l}$ of $\mathrm{KOH} 3 \mathrm{M}$ (Paterson, pers. com.). Commercial kits were used for total dissolved ammonia-N $\left(\mathrm{NH}_{4}{ }^{+}+\mathrm{NH}_{3}\right)$ (Sigma Chemical), glucose (Sigma), lactate (Biomérieux) and magnesium (Biomérieux) determinations. Except for total dissolved ammonia, kits were adapted to a microplate. Absorbance was read on a spectrophotometer (Spectronic Genesys ${ }^{\mathrm{TM}}$ 5) for ammonia. It was read on a microplate reader (Digiscan Asys Hitech 340) for glucose, lactate and magnesium, and concentrations were calculated from a standard curve of substrate. Glucose and lactate were assayed on deproteneized plasma. Plasma level of total proteins was measured by the Lowry et al. (1951) technique adapted to microplate method, using bovine serum albumin (Sigma, molecular weight: 66,000 daltons) as a standard. Ammonia was measured as a control for ammonia-N contamination in shrimps in molt stages $\mathrm{C}$ and $\mathrm{D}_{2}$.

\subsection{Water analysis}

Osmotic pressure of the water was measured as for the haemolymph, with the Wescor osmometer. Total dissolved ammonia-N $\left(\mathrm{NH}_{4}{ }^{+}+\mathrm{NH}_{3}\right)$ concentrations in the water were measured by the Koroleff method (1976) adapted to seawater. Absorbance was read at $630 \mathrm{~nm}$ on the spectrophotometer. Final $\mathrm{NH}_{3}-\mathrm{N}$ concentrations were calculated according to the equation of Bower and Bidwell (1978) based on the final salinity, $\mathrm{pH}$ and temperature of the water in tanks. 


\subsection{Data and statistical analysis}

The OC was calculated as the difference in mOsm $1^{-1}$ of osmotic pressure between seawater and shrimp haemolymph.

The ratio of oxyhaemocyanin to protein was calculated by dividing the concentration of oxyhaemocyanin $\left(\mathrm{mmol} \mathrm{l}^{-1}\right)$ by that of protein $\left(\mathrm{mmol} \mathrm{l}^{-1}\right)$, which was converted from $\mathrm{mg} \mathrm{ml}^{-1}$ to $\mathrm{mmol}^{-1}$ by dividing by 66 (Chen and Cheng, 1993b).

There were not enough animals in stages A and B in the experiment for statistical analysis, thus data analysis was conducted on animals in stages $C, D_{0}, D_{1}$ and $D_{2}$. Data are plotted as mean \pm standard error.

Principal Component Analysis (PCA) was applied to the data designed as observations. All the physiological parameters were defined as variables except the oxyhemocyanin/proteins ratio which is a combination of both parameters. The PCA gives a $n-m$ dimensional plane with the possibility to have, in the same factorial space, observation and variable projections. It was used as a descriptive technique (Statlab computer software).

Data were analysed with two-way and one-way ANOVA followed by the PLSD Fisher test at the significant threshold of 5\% (Statview computer software).

\section{Results}

Figure 1 presents the row projections in the space of the two first correspondence factors $(\mathrm{CF})$ which correspond to axes 1 and 2 on the figure, after submitting data to PCA. This projection plane summarizes $68.8 \%$ of the total variance: $50.6 \%$ for the CF1 and $18.2 \%$ for the CF2. Thirty eight percent of the animals analysed explain $80 \%$ of the first axis (CF1). Amongst the $38 \%$, positive data $(56 \%)$ come from control animals except for one value (treated shrimp in stage C), and mainly from 
intermolt stages ( $77 \%$ of $\mathrm{C}+\mathrm{D}_{0}$ molt stages, $15 \%$ of $\mathrm{D}_{1}, 8 \%$ of $\left.\mathrm{D}_{2}\right)$, and negative ones $(44 \%)$ come all from treated animals mainly in premolt stages $\left(73 \%\right.$ of $\mathrm{D}_{2}, 18 \%$ of $\mathrm{D}_{1}, 9 \%$ of $\mathrm{D}_{0}$ and none of $\mathrm{C}$ ). Eighty $\%$ of the second axis is explained by $23 \%$ of the animals ( $87 \%$ of treated and $13 \%$ of control shrimps).

Data of control shrimps, whatever the stage, are explained mostly by OC, lactate, total proteins and haemocyanin, when treated animals refer more to $\mathrm{Mg}$ ion and glucose concentration.

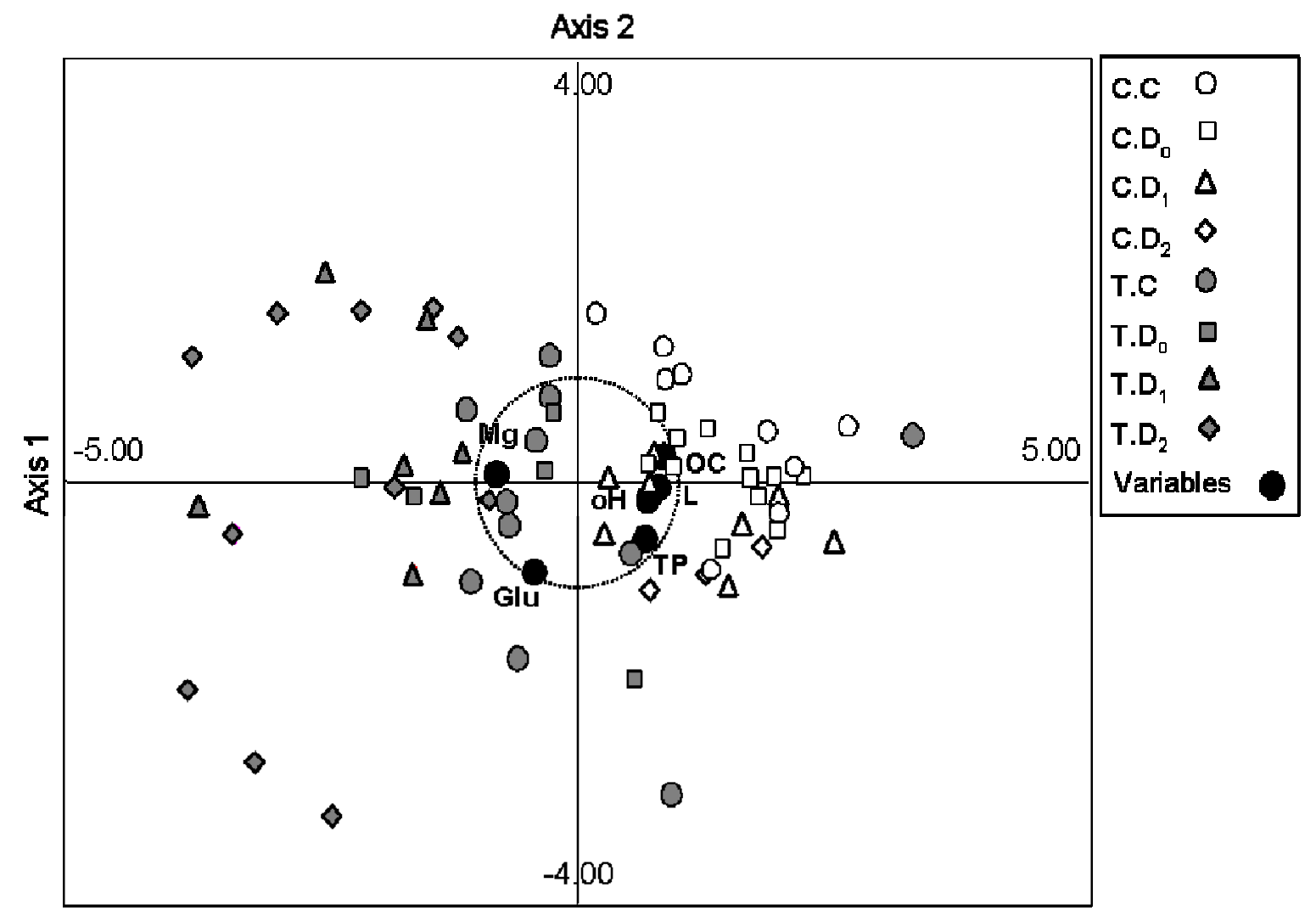

Fig. 1. Row projections in the two first factor space (axes 1 and 2) of the Principal Component Analysis conducted on 6 variables (physiological parameters: osmoregulatory capacity $(\mathrm{OC})$, lactate $(\mathrm{L})$, oxyhaemocyanin $(\mathrm{oH})$, total proteins (TP), glucose (Glu) and $\mathrm{Mg}$ ion $(\mathrm{Mg})$ ) and 92 individual observations taking into account the treatment (control C., treated T.) and the different molt stages. 


\subsection{Effect of short-term exposure to ammonia-N on haemolymph constituents}

Final ambient total ammonia-N concentrations are presented in Table 1. They corresponded to $0.08 \mathrm{mg} \mathrm{l}^{-1} \mathrm{NH}_{3}-\mathrm{N}$ for control tanks and $1.79 \mathrm{mg} \mathrm{l}^{-1} \mathrm{NH}_{3}-\mathrm{N}$ for treated tanks.

Table 1

Mean total ammonia-N concentrations $\left(\mathrm{mg} \mathrm{l}^{-1}\right)$ in the medium and in the haemolymph of the shrimps in stages $\mathrm{C}$ and $\mathrm{D}_{2}$ (Mean \pm standard error)

\section{Medium Haemolymph}

\begin{tabular}{lccc} 
& & Stage C & Stage $\mathrm{D}_{2}$ \\
\hline Control & $2.57 \pm 0.08$ & $2.31 \pm 0.51$ & $4.24 \pm 1.05$ \\
& & $(\mathrm{n}=18)$ & $(\mathrm{n}=8)$ \\
24h ammonia treatment & $54.60 \pm 2.50$ & $45.99 \pm 2.59$ & $50.96 \pm 3.32$ \\
& & $(\mathrm{n}=10)$ & $(\mathrm{n}=10)$ \\
\hline
\end{tabular}

Ammonia-N in the haemolymph of control shrimps (Table 1) were not significantly different between stages $C$ and $D_{2}(p>0.05)$. No difference was also observed in the ammonia treated group $(\mathrm{p}>0.1)$. No mortality was recorded during the experiment. Ammonia exposure treatment increased variability between individuals as shown on Figure 1 (PCA). It had an overall (all molt stages combined) significant effect on all parameters $(\mathrm{p} \leq 0.0018)$, except for the oxyhaemocyanin/total protein ratio. Haemolymph glucose and $\mathrm{Mg}$ ion levels were significantly higher after $24 \mathrm{~h}$ treatment, while a significant decrease was observed for OC, lactate, total proteins and oxyhaemocyanin levels (Fig. 2). OC ( $\mathrm{p} \leq 0.0055)$, lactate $(\mathrm{p} \leq 0.0134)$ and $\mathrm{Mg}$ 
ion $(\mathrm{p} \leq 0.0020)$ concentrations were affected at all stages. Ammonia-N treatment decreased OC for $30 \%$ (stage C) to $56 \%\left(\right.$ stage $\mathrm{D}_{2}$ ) (Fig. $2 \mathrm{~A}$ ), lactate level for $37 \%$ (stage C), $42 \%$ (stages $\mathrm{D}_{0}$ and $\mathrm{D}_{2}$ ) and $53 \%$ (stage $\mathrm{D}_{1}$ ) (Fig. $2 \mathrm{~F}$ ). An increase of $70 \%$ (stage C) to $120 \%$ (stage $\mathrm{D}_{2}$ ) was observed for $\mathrm{Mg}$ ions concentration (Fig. 2B). Plasma glucose level did not change for stages $\mathrm{D}_{1}$ and $\mathrm{D}_{2}$, but ammonia treatment increased glucose levels by $30 \%$ in stage $\mathrm{C}$ and $25 \%$ in stage $\mathrm{D}_{0}$ (Fig. 2G). No differences between control and treated animals in stages $\mathrm{C}$ and $\mathrm{D}_{0}$ were observed for total proteins level (figure C) and oxyhaemocyanin concentration (Fig. 2D), when total proteins and oxyhaemocyanin concentration in stages $D_{1}$ and $D_{2}$ decreased similarly between 17 to $20 \%$.

\subsection{Effect of molt stage and sex on haemolymph constituents}

A significant difference $(\mathrm{p}<0.02)$ between stages was observed in control shrimps for OC (Fig. 2A), Mg ion (Fig. 2B), and total proteins (Fig. 2C). The highest OC (163 \pm $3 \mathrm{mOsm} \mathrm{l}^{-1}$ ) was observed in stage $\mathrm{C}$, and the lowest $\left(131 \pm 13 \mathrm{mOsm}^{-1}\right)$ in stage $\mathrm{D}_{2}$ (Fig. 2A). $\mathrm{Mg}$ ion concentration was lower in stage $\mathrm{C}\left(7.3 \pm 0.4 \mathrm{mmol} \mathrm{l}^{-1}\right)$ compared to stages $\mathrm{D}_{1}\left(10.2 \pm 0.4 \mathrm{mmol} \mathrm{l}^{-1}\right)$ and $\mathrm{D}_{0}\left(9.4 \pm 0.2 \mathrm{mmol} \mathrm{l}^{-1}\right)$, but not stage $\mathrm{D}_{2}(8.4 \pm$ $0.6 \mathrm{mmol} \mathrm{l}^{-1}$ ) (Fig. 2B). Total proteins level was significantly higher in stages $\mathrm{D}_{0}$ and $\mathrm{D}_{1}$ compared to stage $\mathrm{C}$ (Fig. 2C). No differences were observed for oxyhaemocyanin concentration, oxyhaemocyanin/total proteins ratio, lactate and glucose levels. Differences between molt stages disappeared after $24 \mathrm{~h}$ ammonia-N treatment for total proteins $(\mathrm{p}>0.05)$. However, levels of $\mathrm{Mg}$ ion were significantly higher $(\mathrm{p}<0.05)$ in stages $\mathrm{D}_{1}$ and $\mathrm{D}_{2}$ compared to stage $C$. Differences between stages appeared for lactate level after $24 \mathrm{~h}$ ammonia-N treatment $(\mathrm{p}<0.01)$. Mean lactate 
levels in stages $\mathrm{D}_{1}\left(12.3 \pm 1.5 \mathrm{mg} \mathrm{dl}^{-1}\right)$ and $\mathrm{D}_{2}\left(11.3 \pm 0.7 \mathrm{mg} \mathrm{dl}^{-1}\right)$ were lower than that in stage $\mathrm{C}\left(17.3 \pm 1.2 \mathrm{mg} \mathrm{dl}^{-1}\right)$ (Fig. 2F).

No differences were observed between male and female ( $\mathrm{P}>0.20$ for all parameters).
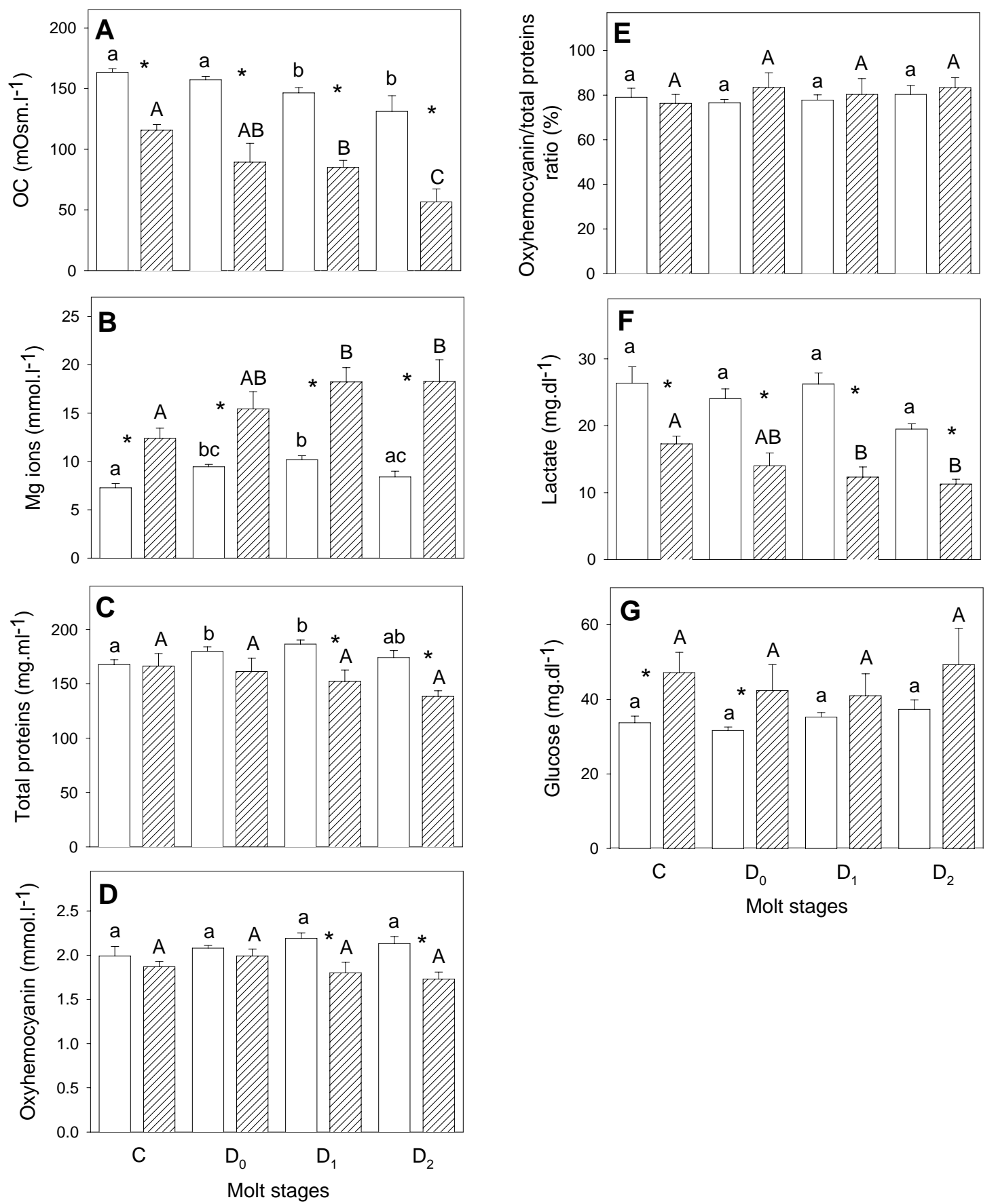
Fig. 2. Mean ( \pm S.E.) osmoregulatory capacity (OC) (A), Mg ion (B), total proteins (C), oxyhaemocyanin (D), oxyhaemocyanin/total proteins ratio (E), lactate (F) and glucose $(\mathrm{G})$ concentrations in the haemolymph of $\underline{\mathrm{L} \text {. stylirostris }}$ at different molt stages. Comparisons of controls (open bars) with shrimps exposed to ammonia (bars with pattern). Mean values from 16-18 determinations for control stages C, Do, D1; 3-8 determinations for control stage D2, and 5-11 determinations for treated animals. Bars within control or treatment groups with different letters are significantly different $(\mathrm{p}<0.05)$. Significant difference between control and treated animals are shown by *.

\section{Discussion}

\subsection{Ammonia levels}

Ambient ammonia in control tanks was below the safe level defined for $\underline{P \text {. monodon }}$ adolescent (4.26 $\mathrm{mg} \mathrm{l}^{-1}$ ammonia-N), and the $\mathrm{NH}_{3}-\mathrm{N}$ concentration was equivalent to the safe level $\left(0.08 \mathrm{mg}^{-1}\right)$ (Chen et al., 1990), or below the safe level defined for $\underline{P}$. vannamei $\left(0.16 \mathrm{mg} \mathrm{l}^{-1} \mathrm{NH}_{3}-\mathrm{N}\right.$ (Lin and Chen, 2001).

Mean haemolymph ammonia-N level in control shrimp in stage $\mathrm{C}$ was close to the value observed in control $\underline{\mathrm{P} \text {. chinensis }}(27 \mathrm{~g}$ weight $)\left(2.71 \pm 0.04 \mathrm{mg}^{-1}\right)$ by Chen et al. (1993), and lower than that observed in $\underline{\mathrm{P} \text {. japonicus }}\left(4.45 \pm 0.44 \mathrm{mg} \mathrm{l}^{-1}\right.$ (stage C, 14g) (Chen and Kou, 1991). Haemolymph ammonia concentration of treated shrimps in stage $\mathrm{C}$ reached $84 \%$ of the ambient ammonia- $\mathrm{N}$ concentration, which is similar to what was obtained by Chen et al. (1993) in stage $\mathrm{C}$ adults of $\underline{\mathrm{P} \text {. chinensis }}(80 \%)$ after $24 \mathrm{~h}$ treatment with $20 \mathrm{mg} \mathrm{l}^{-1}$ ammonia-N. An increase of ammonia in the plasma with increasing ambient ammonia-N concentration was also observed by Chen and

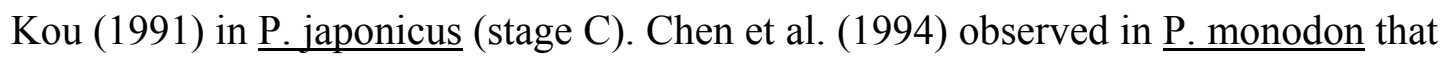


net ammonia-N uptake occurred at ambient ammonia- $\mathrm{N}$ greater than $5 \mathrm{mg}^{-1}$ after 24h exposure. Final $\mathrm{NH}_{3}-\mathrm{N}$ ambient concentration in treated tanks $\left(1.79 \mathrm{mg}^{-1}\right)$ was less than the $2 \mathrm{mg} \mathrm{l}^{-1}$ expected. However, it was above the safety level (Lin and Chen, 2001) and below the lethal level, as no mortality was recorded during the $24 \mathrm{~h}$ experiment, whatever the molt stage. Only a few shrimps seemed to be weak after $24 \mathrm{~h}$ exposure. In comparison, no mortalities were recorded in adolescent $\underline{\mathrm{P} \text {. monodon }}$ (5g) exposed for $24 \mathrm{~h}$ to $90 \mathrm{mg} \mathrm{l^{-1 }}$ ammonia-N (1.62 mg.1 ${ }^{-1} \mathrm{NH}_{3}$ ), or for $72 \mathrm{~h}$ to $50 \mathrm{mg}$ $1^{-1}\left(0.90 \mathrm{mg}^{-1} \mathrm{NH}_{3}\right)$ (Chen et al., 1990). Moreover, the duration of treatment was shorter than the $\mathrm{LT}_{50}$ (the time required to kill half of the population) defined by Chen et al. (1990), which were $114 \mathrm{~h}$ for shrimps exposed to $50 \mathrm{mg}^{-1}$ ammonia-N and $31.2 \mathrm{~h}$ for shrimps exposed to $100 \mathrm{mg} \mathrm{l}^{-1}\left(1.80 \mathrm{mg} \mathrm{l}^{-1} \mathrm{NH}_{3}\right)$.

\subsection{Internal effect due to molt cycle (control shrimp)}

The blue shrimp L. stylirostris is a hypo-osmoregulator in 32 \%o seawater. However, the difference of osmolarity between the medium and the haemolymph is reduced during molting. Dependence on external factors gradually declines in older molt stages suggesting a reduction in integument permeability as the exoskeleton hardens (Hunter and Uglow, 1993). We observed in our study that OC decreased with the late premolt stages. A correlation with molt stage was also observed on total proteins and $\mathrm{Mg}$ ion with a slight but significant increase of concentration during the early premolt stages and then a decrease, which could be attributed to haemolymph dilution before ecdysis. In Crangon crangon, reasonably constant total proteins concentrations are maintained during early to mid premolt stages, but drop between late premoult and immediate premoult (Hunter and Uglow, 1993). In other species

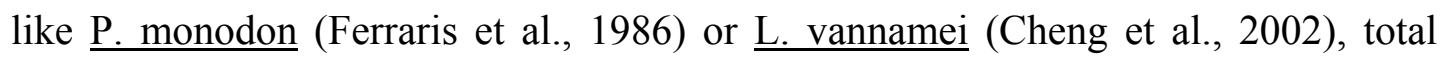


protein concentrations remained stable throughout the molting cycle. No effect due to molt cycle was observed on glucose, oxyhaemocyanin and the hemocyanin/total proteins ratio.

\subsection{External effect due to ammonia treatment}

Ammonia treatment affected the shrimps as shown by the variation of most of the physiological parameters studied. Effect of ammonia on osmoregulation has been demonstrated in $\underline{P}$. japonicus and the American lobster Homarus americanus (Young-

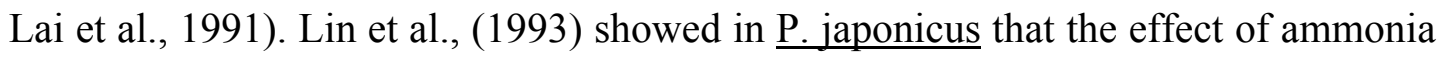
on osmoregulation was dose- and exposure-time dependant, and the effect reversible. They suggested that the decrease in $\mathrm{OC}$ was the result of an impaired $\mathrm{Na}^{+}$and $\mathrm{Cl}^{-}$ regulation. Decrease in haemolymph total proteins with increased ambient ammonia$\mathrm{N}$ may be due to an increase in catabolism of proteins to adjust osmoregulation (Ferraris et al., 1986). Decrease of both total proteins and oxyhaemocyanin when animals are exposed to ambient ammonia is probably a result of proteolysis as

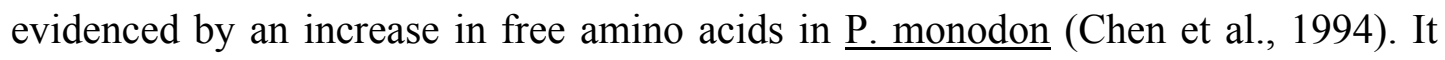
may also result of an increased permeability to water under ammonia exposure. Similarly, increase in $\mathrm{Mg}$ ion concentration under stress (capture, air exposure) was reported by Boglio and Goarant (1996) for L. stylirostris, which may be due to impaired osmoregulation and flow into the haemolymph by diffusion.

Racotta and Hernandez-Herrera (2000) observed that oxygen consumption increases

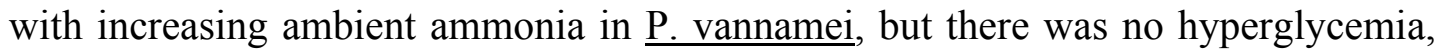
nor significant decrease of lactate. These authors suggested a reduced use of carbohydrate through anaerobic metabolism in shrimp exposed during $24 \mathrm{~h}$ to 30.2 mg. $1^{-1}$ ammonia-N. In our study we do observe a decrease in lactate level, and an 
increase in glucose concentration, at least in stages $C$ and $D_{0}$. It is possible that the ambient concentration of ammonia, which was 1.8 times higher in our studies (54.6 $\mathrm{mg}^{-1}$ ) lead to an increased effect on shrimp physiology. To our knowledge, there are no other works published on the effect of ambient ammonia on shrimp glucose and lactate levels in haemolymph.

\section{4. $\underline{\text { Combined effect of ammonia and molt stage }}$}

A two-way ANOVA showed that there was no interaction between treatment and molt stage except for total proteins $(p<0.05)$. Even if the environmental effect seems stronger than internal effect (molt cycle), the PCA representation shows that shrimps in stage $D_{2}$ and, in a less extend, $D_{1}$ present a higher variability and a stronger physiological response to ammonia than animals in stages $C$ and $D_{0}$, indicating that stages $D_{1}$ and $D_{2}$ seem to be more sensitive to ammonia than $C$ and $D_{0}$ animals. The PLSD Fisher test confirms this observation: Only shrimps in stages $D_{1}$ and $D_{2}$ show significant differences for parameters like total proteins and oxyhaemocyanin. Moreover, for $\mathrm{OC}$ and $\mathrm{Mg}$ ion, the difference in levels between control and treated shrimps is greater in stage $\mathrm{D}_{2}$ compared to stage $\mathrm{C}$ (respectively 2.3 and 2.2 fold for $\mathrm{D}_{2}$ against 1.4 and 1.6 for $\left.\mathrm{C}\right)$. Similarly, $\underline{\mathrm{L} \text { stylirostris }}$ submitted to experimental hypoxia show a decrease of OC twice more important in stage $\mathrm{D}_{2}$ than in stage $\mathrm{C}$, and a higher rate of mortality in stage $\mathrm{D}_{2}$ than in intermolt stage (Mugnier and Soyez, 2001). On the other hand, glucose increase in treated shrimps is significant for animals in stages $C$ and $D_{0}$, but not for stages $D_{1}$ and $D_{2}$. Hardy and al. (1994)

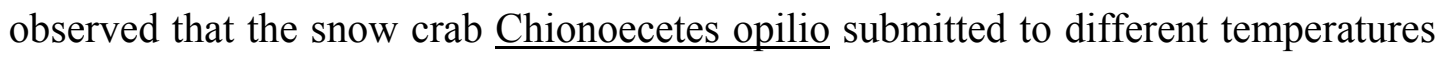
showed a greater increase of glucose concentration at a lower temperature in hardshell crabs than in soft-shell ones. The authors suggested that it could be due to lower 
reserves of glycogen in the soft-shell crabs and by the dilution effect of their greater plasma volume. Combined effects of stress and molt stage on physiological response of crustacean are very poorly documented. However it is important to understand these interactions as in aquaculture it is suggested that the shrimps are more sensitive to disease during the molting period when environment is less favourable to the shrimps (Mermoud et al., 1998; Horowitz and Horowitz, 2001). To our knowledge, only the effects of separate factors (i.e. environmental stress or molt stage) on the response to experimental infection have been studied. Thus it has been shown that $\underline{\mathrm{L}}$ $\underline{\text { stylirostris (Le Moullac et al., 1997) and the giant freshwater prawn Macrobrachium }}$

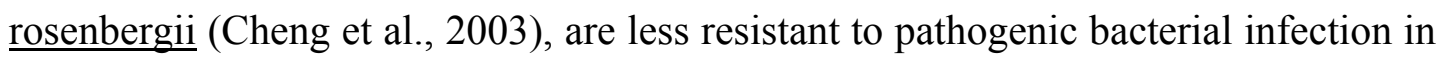
premolt stage than in stage C. On the other hand, a hypoxic stress decreases the resistance of intermolt $\underline{\underline{L} \text {. stylirostris }}$ to Vibrio infection (Le Moullac et al., 1998). In New Caledonia a large part of the population carry the Vibrio responsible for outbreaks (Goarant, pers. Com.). However, the disease is not systematic, and triggering factors may be implied. Theses factors can as well be external (environment) as internal (molting) or a combination of both.

\subsection{Physiological parameters as tools for stress detection}

The ability to detect a physiological stress before it causes irreversible damage or death, and in aquaculture to monitor the health of animals, may be obtained by the measure of physiological parameters (Lignot et al., 2000). Coupled with the measure of some environmental parameters (including oxygen, ammonia, temperature), they could be management tools to eliminate or reduce stress factors and improve shrimp health. For this, physiological parameters need to be sensitive and reliable. OC is already known as a good but non-specific stress indicator (Lignot et al., 2000). 
However, its use is limited to controlled conditions because it is external salinity dependent. As shown on the PCA, Mg ion and, to a lesser extent, glucose seem to be good candidates. Boglio and Goarant (1996) pointed out that $\mathrm{Mg}$ ion could be a good stress indicator, at least for acute stress, for $\underline{L}$. stylirostris and for $\underline{P \text {. monodon. }}$ Hyperglycaemia is an indicator of short-term stress (Hall and Van Ham, 1998). A decrease of glucose level can also be observed when perturbation last longer (Hagerman et al., 1990). Results of Racotta and Palacios (1998) on stress of experimental manipulation (repeated sampling) in $\underline{P \text {. vannamei }}$ let suggest that circulating levels of glucose, rather than lactate, appears to be a more sensitive stress indicator. Our recent field surveys tend to confirm interest of both $\mathrm{Mg}$ ion and glucose rather than lactate as tools for stress detection (unpublished data). Total proteins and oxyhaemocyanin are also promising candidates. Concentration of ammonia in haemolymph could also be used as an index of ammonia loading for $\underline{\mathrm{L}}$.

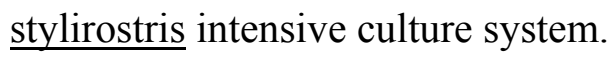

\section{Acknowledgement}

This work was supported by research grants from the North and South Provinces of New Caledonia. The authors would like to thank Ifremer staff who helped to catch the shrimps and gave technical assistance.

\section{References}


Boglio, E., 1995. Measurement of stress in broodstock leader prawns (Penaeus monodon) following capture by trawling and transport to hatcheries. $\mathrm{PhD}$, University of Queensland, Queensland. $155 \mathrm{pp.}$

Boglio, E., Goarant, C., 1996. Hemolymph magnesium as a measure of acute physiological stress in wild broodstock Penaeus monodon and cultured broodstock P. stylirostris. In "Second International Conference on the Culture of Penaeid Prawns and shrimps”, pp. 101, Iloilo, Philippines.

Bower C.E., Bidwell J.P., 1978. Ionization of ammonia in seawater: effects of temperature, $\mathrm{pH}$ and salinity. Journal of the Fisheries Research Board of Canada $35,1012-16$.

Chan, S.-M., Rankin, S. M., Keeley, L. L., 1988. Characterization of the molt stages in Penaeus vannamei: setogenesis and hemolymph levels of total protein, ecdysteroids, and glucose. Biological Bulletin 175, 185-192.

Chen, J.-C., Cheng, S.-Y., 1993a. Hemolymph PCO2, hemocyanin, protein levels and urea excretions of Penaeus monodon exposed to ambient ammonia. Aquatic Toxiciology 27, 281-292.

Chen J.-C. Cheng S.-Y., 1993b. Studies on haemocyanin and haemolymph protein levels of Penaeus japonicus based on sex, size and moulting cycle. Comparative Biochemistry and Physiology 106B(2): 293-296.

Chen, J.-C., Kou, Y.-Z., 1991. Accumulation of ammonia in the hemolymph of Penaeus japonicus exposed to ambient ammonia. Diseases of Aquatic Organisms 11, 187-191.

Chen, J.-C., Chen, C.-T., Cheng, S.-Y., 1994. Nitrogen excretion and changes of hemocyanin, protein and free amino acid levels in the hemolymph of Penaeus 


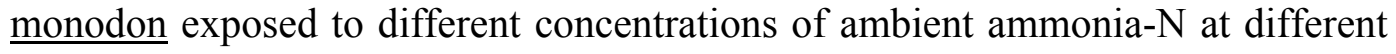
salinity levels. Marine Ecology Progress Series 110, 85-94.

Chen, J.-C., Liu, P.-C., Lei, S.-C., 1990. Toxicities of ammonia and nitrite to Penaeus monodon adolescents. Aquaculture 89, 127-137.

Chen, J.-C., Nan, F.-H., Cheng, S.-Y., Sheen, S.-S., 1993. Effects of ambient ammonia on ammonia-N and protein concentrations in hemolymph and ammoniaN excretion of Penaeus chinensis. Marine Ecology Progress Series 98, 203-208.

Cheng, W., Juang, F.-M., Li, J.-T., Lin, M.-C., Liu, C.-H., Chen, J.-C., 2003. The immune response of the giant freshwater prawn Macrobrachium rosenbergii and its susceptibility to Lactococcus garvieae in relation to the moult stage. Aquaculture 218, 33-45.

Cheng, W., Liu, C.-h., Yan, D.-F., Chen, J.-C., 2002. Hemolymph oxyhemocyanin, protein, osmolality and electrolyte levels of whiteleg shrimp Litopenaeus vannamei in relation to size and molt stage. Aquaculture 211, 325-339.

Claybrook D.L., 1983. Nitrogen metabolism. In: Mantel L.H. (ed.). The Biology of Crustacea, Vol. 5, Internal anatomy and physiological regulation. Academic Press, New York, pp.162-213.

Colt, J.E., Armstrong, D.A., 1981. Nitrogen toxicity to crustaceans, fish and molluscs. In: Allen, L.J., Kinney, E.C. (Eds.), Proceedings of the BioEngineering Symposium for Fish Culture. Fish Culture Section. American Fisheries Society, Northeast Society of Conservation Engineers, Bethesda, Maryland, pp. 34-47.

Costa, R., Mermoud, I., Koblavi, S., Morlet, B., Haffner, P., Berthe, F., LeGroumellec, M., Grimont, P., 1998. Isolation and characterization of bacteria 
associated with Penaeus stylirostris disease (syndrome 93) in New Caledonia. Aquaculture 164, 297-309.

Drach P., 1939. Mue et cycle d'intermue chez les crustacés décapodes. Annales de l'Institut Océanographique de Paris N. S. 19, 103-391.

Ferraris, R. P., Parado-Estepa, F. D., deJesus, E. G., Ladja, J. M., 1986. Osmoregulation in Penaeus monodon: effects of molting and external salinity. In: Maclean, J.L., Dizon L.B., Hosillos, L.V. (Eds.), The first Asian fisheries forum. Asian Fisheries Society, Manila, Philippines., pp. 637-640.

Hagerman, L., Sondergaard, T., Weile, K., Hosie, D., Uglow, R. F., 1990. Aspects of blood physiology and ammonia excretion in Nephrops norvegicus under hypoxia. Comparative Biochemistry and Physiology 97A, 51-55.

Hall, M. R., VanHam, E. H., 1998. The effects of different types of stress on blood glucose in the giant tiger prawn Penaeus monodon. Journal of the World Aquaculture Society 29, 290-299.

Hardy, D., Munro, J., Dutil, J.-D., 1994. Temperature and salinity tolerance of the soft-shell and hard-shell male snow crab, Chionoecetes opilio. Aquaculture 122, 249-265.

Harris, R. R., Coley, S., Collins, S., McCabe, R., 2001. Ammonia uptake and its effects on ionoregulation in the freshwater crayfish Pacifastacus leniusculus (Dana). Journal of Comparative Physiology B 171, 681-693.

Horowitz, A., Horowitz, S., 2001. Disease control in shrimp aquaculture from a microbial ecology perspective. In: Browdy C.L., Jory D.E. (Eds.), Proceedings of the Special Session on Sustainable Shrimp Culture, Aquaculture 2001. The World Aquaculture Society, Baton Rouge, LA, USA, pp. 199-218. 
Hunter, D. A., Uglow, R. F., 1993. Moult stage-dependent variability of haemolymph ammonia and total protein levels of Crangon crangon (L.) (Crustacea, Decapoda). Ophelia 37, 41-50.

Koroleff F., 1976. Determination of ammonia. In: Grasshof K. (Ed), Methods in seawater analysis, Verlag chemie, Weineim, RFA, pp. 126-133.

Le Moullac, G., Haffner, P., 2000. Environmental factors affecting immune responses in Crustacea. Aquaculture 191, 121-131.

Le Moullac, G., LeGroumellec, M., Ansquer, D., Froissard, S., Lecy, P., Aquacop, 1997. Haematological and phenoloxidase activity changes in the shrimp Penaeus

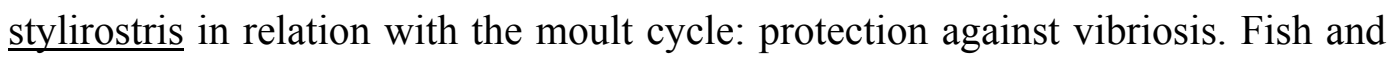
Shellfish Immunology 7, 227-234.

Le Moullac, G., Soyez, C., Saulnier, D., Ansquer, D., Acvarre, J.-C., Levy, P., 1998. Effect of hypoxic stress on the immune response and the resistance to vibriosis of the shrimp Penaeus stylirostris. Fish and Shellfish Immunology 8, 621-629.

Lignot, J. H., Spanings-Pierrot, C., Charmantier, G., 2000. Osmoregulatory capacity as a tool in monitoring the physiological condition and the effect of stress in crustaceans. Aquaculture 191, 209-245.

Lin, Y.-C., Chen, J.-C., 2001. Acute toxicity of ammonia on Litopenaeus vannamei Boone juveniles at different salinity levels. Journal of Experimental Marine Biology and Ecology 259, 109-119.

Lin, H.-P., Thuet, P., Trilles, J., Mounet-Guillaume, R., Charmantier, G., 1993. Effects of ammonia on survival and osmoregulation of various development stages of the shrimp Penaeus japonicus. Marine Biology 117, 591-598.

Lowry O.H., Rosebrough N.F., Farr A.L., Randall R.J., 1951. Protein measurement with the Folin phenol reagent. Journal of Biology and Chemistry 193, 251. 
Mermoud, I., Costa, R., Ferré, O., Goarant, C., Haffner, P., 1998. "Syndrome 93" in New Caledonian outdoor rearing ponds of Penaeus stylirostris: history and description of three major outbreaks. Aquaculture 164, 323-335.

Morritt, D., Spicer, J. I., 1993. A brief re-examination of the function and regulation of extracellular magnesium and its relationship to activity in crustacean arthropods. Comparative Biochemistry and Physiology 106A, 19-23.

Mugnier, C., Soyez, C., 2001. Effect of temperature decrease, hypoxia and molt stage on osmoregulatory capacity and survival in the penaeid shrimp Litopeneaus

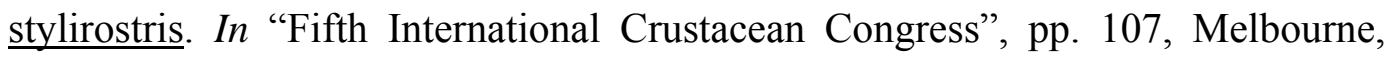
Australia.

Paul, R. J., Pirow, R., 1997/98. The physiological significance of respiratory proteins in invertebrates. Zoology 100, 298-306.

Racotta, I. S., Hernandez-Herrera, R., 2000. Metabolic responses of the white shrimp, Penaeus vannamei, to ambient ammonia. Comparative Biochemistry and Physiology A 125, 437-443.

Racotta, I. S., Palacios, E., 1998. Hemolymph metabolic variables in response to experimental manipulation stress and serotonin injection in Penaeus vannamei. Journal of the World Aquaculture Society 29, 351-356.

Schmitt, A. S. C., Uglow, R. F., 1997. Effects of ambient ammonia levels on blood ammonia, ammonia excretion and heart and scaphognathite rates of Nephrops norvegicus. Marine Biology 127, 411-418.

Soyez, C., 1997. Evaluation des conséquences d'une situation hypoxique simulée sur la capacité osmorégulatrice des crevettes d'élevage, Penaeus stylirostris et Penaeus vannamei. Internal Report, COP IFREMER, Tahiti, 50 pp. 
Wajsbrot, N., Gasith, A., Krom, M. D., Samocha, T. M., 1990. Effect of dissolved oxygen and the molt stage on the acute toxicity of ammonia to juvenile green tiger prawn Penaeus semisulcatus. Environmental Toxicology and Chemistry 9, 497504.

Young-Lai, W. W., Charmantier-Daures, M., Charmantier, G., 1991. Effect of ammonia on survival and osmoregulation in different life stages of the lobster Homarus americanus. Marine Biology 110, 293-300. 